\title{
The Impact of the Jordanian Labor Culture on the Low Employment Rates in the Sectors of Engineering, Plastic, Rubber Industries, Printing, Paper and Packaging Compared to Other Industrial Sectors in Abdullah II Industrial City
}

\author{
Khaled Abd Almanem Albustanji ${ }^{1}$, Mohammad Salameh Almahirah ${ }^{1}$, Moh'd Ahmad Abd-Qader ${ }^{1}$, Mohammad \\ Al-Qaryouti ${ }^{2}$ \\ ${ }^{1}$ Dr., Department of Business Management, Faculty of Business, Al-Isra University, Amman-Jordan \\ ${ }^{2}$ Department of Business Management, Faculty of Business, Al-Isra University, Amman-Jordan \\ Correspondence: Khaled Abd Almanem Albustanji, Dr., Department of Business Management, Faculty of \\ Business, Al-Isra University, Amman-Jordan.
}

\author{
Received: March 18, $2019 \quad$ Accepted: April 24, $2019 \quad$ Online Published: April 29, 2019 \\ doi:10.5539/ibr.v12n5p167 URL: https://doi.org/10.5539/ibr.v12n5p167
}

\begin{abstract}
The study aimed to identify the effect of the Jordanian labor culture on the low operating rates in the sectors of engineering, plastic and rubber industries, printing, paper and packaging compared to other industrial sectors in Abdullah II Industrial City. The study reached a number of results, the most important of which is that there is an impact on the Jordanian labor culture on the low operating rates in the sectors of engineering, plastic and rubber industries, printing, paper and packaging compared with other industrial sectors. The study presented several recommendations, the most important of which is to raise or reconsider material and moral incentives in the sectors subject to study by the competent authorities, so that they are fair and appropriate to the nature of work in these sectors under the specified working hours. The State continues to provide all available means to prepare the worker technically and physically to work in the sectors studied through the training centers prepared for the Jordanian workers to train and enroll in these sectors through appropriate material and financial support.
\end{abstract}

Keywords: Jordanian labor, unemployment, Abdullah II Industrial City

\section{Introduction}

The Hashemite Kingdom of Jordan suffers from high rates of unemployment, where the unemployment rate in the Kingdom reached (17\%) in 2017, and the Jordanian authorities try to solve or alleviate this problem by creating more job opportunities for young people in all public and private institutions, including the Industrial Estates Corporation.

The Industrial Estates Corporation is one of the pillars of the Jordanian economy that hoped for to provide job opportunities for Jordanian youth, but unemployment of Jordanians in some industrial sectors outweigh Jordanian labor, although the Jordanian legislation refers to the need for priority of employment of the Jordanian labor. Therefore, this study tries to clarify the impact of the Jordanian labor culture on the low employment rates in the sectors of engineering, plastic and rubber industries, printing, paper and packaging compared to other industrial sectors in Abdullah II Industrial City.

\subsection{Objectives of the Study}

This study aims to achieve the following objectives:

1 - To know whether there is an impact of the Jordanian labor culture on the low employment rates in the sectors of engineering, plastic and rubber industries, printing, paper and packaging compared to other industrial sectors in Abdullah II Industrial City.

2 - Identify all industrial sectors in the city of Abdullah II Industrial City, and the numbers of Jordanian and non-Jordanian workers in these sectors.

3 - Understand the concept of the industrial sectors (engineering, plastic, rubber, printing, paper and packing). 
4 - Analyze the results and accordingly present some suggestions and recommendations that will help the management of the Abdullah II Industrial City and related bodies to diagnose the reality of employment and correct the imbalance, if any.

\subsection{The Problem of the Study and Its Questions}

The Jordanian youth seek to find employment opportunities in all public and private institutions and in various industrial, commercial, services and other sectors. Several concerned parties, including the State, are interested in achieving this endeavor to find a solution to, or alleviate the problem of unemployment.

The Abdullah II Industrial City is the first industrial city and the largest industrial establishment complex, which is hoped for to provide job opportunities for Jordanian youth. However, after reviewing the numbers of workers and their nationalities in all industrial sectors in this city, we found a decline in the employment rates of Jordanians in three industrial sectors: The sectors of the engineering industry, plastic and rubber, printing, paper and packaging compared with other industrial sectors.

Therefore, the problem of the study can be formulated in the following main question:

Is there an impact of the Jordanian labor culture on the low employment rates in the sectors of engineering, plastics and rubber industries, printing, paper and packaging compared to other industrial sectors in Abdullah II Industrial City?

\subsection{Hypotheses of the Study}

In light of the main question of the study, the following main hypothesis was formulated:

(H0) The main hypothesis of the study: There is no statistically significant effect at the level of $\alpha(0.05)$ of the Jordanian labor culture on the low employment rates in the sectors of engineering, plastics and rubber industries, printing, paper and packaging compared with other industrial sectors in Abdullah II Industrial City.

\subsection{Methodology of the Study}

1 - The researcher conducted an initial survey of a number of managers in the companies engaged in the sectors of engineering, plastic and rubber, printing, paper and packaging. The majority of them indicated that the low rates of employment of Jordanian workers in these sectors are due to the Jordanian labor culture and attitudes towards these Industries.

2 - To achieve the objective of the study, the study adopted the descriptive analytical method, which is based on the study of the current reality of the impact of the Jordanian labor culture on the low employment rates in the sectors of engineering, plastic and rubber industries, printing, paper and packaging compared to other industrial sectors in Abdullah II Industrial City, using the field study to obtain data and information through a questionnaire designed for this purpose, which was distributed to the sample of the study, and then the data and information were analyzed statistically for the purpose of testing the hypothesis of study according to the proposed study model.

\subsection{Study Model}

The study model included a structural breakdown of the following study variables:

\section{A- Independent variable: Jordanian worker culture}

B - The dependent variable: low employment rates in the sectors of the industries of (engineering, plastic and printing) in Abdullah II Industrial City

Independent variable

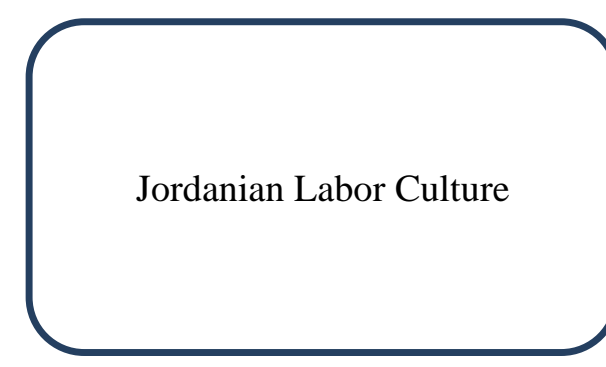

Figure 1. Study model
The dependent variable

Low employment rates in the industrial, engineering and printing sectors in Abdullah II Industrial City

Prepared by the researcher based on the methodology of the study 


\subsection{Measurement of Study Variables}

The dependent and Independent variables will be measured through a questionnaire which is prepared and distributed to a number of administrators in the companies engaged in the sectors of engineering, plastic and rubber, printing, paper and packaging.

The study tool included a number of items to measure the impact of the Jordanian labor culture on low employment rates in the sectors of engineering, plastics, rubber, printing, paper and packaging industries compared to other industrial sectors in Abdullah II Industrial City. All questions will be of the close type in accordance with the Likert scale.

\subsection{Limits and Limitations of Study (Place and Type of Study)}

The scope of the study will be as follows:

1. Place Limitation: This study is limited to the Jordanian companies operating in the sectors of engineering, plastics and rubber, printing, paper and packaging industries in Abdullah II Industrial City.

2. Sample Limitations: This study will be applied to the administrators of the companies in the engineering, plastic and rubber industries, printing, paper and packaging. The study sample will represent $16 \%$ of the study population.

\subsection{Operational Definitions of the Study}

Worker culture: a set of ethical and behavioral values and principles that aim to improve the behavior of the worker. (Business Culture Report, 2016 " https://mawdoo3.com ")

Abdullah II Industrial City: It is an industrial city established in 1984. It is the first industrial city to be established. It is the largest industrial complex of the Industrial Cities Company and contains 10 industrial sectors. (Annual Report of Abdullah II Industrial City, 2017)

\section{Theoretical Framework}

In this chapter, the concept of Jordanian labor will be clarified, and definitions will be presented for Abdullah II Industrial City, the industrial sectors operating in this city, and the total number of companies and the number of workers in these sectors.

\section{Worker culture}

The culture of the worker consists of a set of moral and behavioral values and principles that aim to improve functional behavior. (Business Culture Report, 2016 "https://mawdoo3.com")

\section{Jordanian Labor}

Jordanian Employment: is the local employment of workers that hold a Jordanian nationality.

\section{Characteristics of Jordanian labor}

The majority of non-Jordanian workers are between 18 and 55 years of age. The number of married Jordanian workers exceeds the number of unmarried Jordanian workers. The percentage of married Jordanian workers is $66 \%$, while the percentage of unmarried Jordanian workers is 34\%. (Ababneh et al., 2014, 14)

\section{Abdullah II Industrial City}

Abdullah II Industrial City was established in 1984. It is the first industrial city to be established. It is considered the largest industrial complex of establishments in the Industrial Cities Company. The city is located $12 \mathrm{~km}$ southeast of Amman. The total area of the city is 2530 dunums. The percentage of use of places in the city is $100 \%$. (Annual Report of Abdullah II Industrial City, 2017). 
Total number of companies and employment for all nationalities in all industrial sectors in Abdullah II Industrial City

The total number of companies and manpower for all nationalities in all industrial sectors operating in Abdullah II Industrial City can be illustrated in Table (2.1) below:

Table 2.1 shows the total number of companies and workers of all nationalities in all industrial sectors operating in Abdullah II Industrial City

\begin{tabular}{ccc}
\hline Industrial sector & Number of companies & Number of employees \\
\hline Food industries & 56 & 3453 \\
Pharmaceutical Industries & 21 & 1128 \\
Engineering (metal and electrical) & 84 & 1826 \\
Plastic and rubber & 92 & 2338 \\
Chemical industries & 76 & 1356 \\
Textile and cotton & 32 & 333 \\
Furniture, Kitchens \& Doors & 13 & 3084 \\
Printing, paper and packaging & 42 & 21 \\
Leather Industries & 5 & 154 \\
Construction Industries & 11 & 14356 \\
\hline
\end{tabular}

Source: Annual Report of Abdullah II Industrial City, 2017.

Total number of Jordanian and non-Jordanian labor in all industrial sectors in Abdullah II Industrial City

The total number of Jordanian and non-Jordanian workers and the percentage of Jordanian labor in all industrial sectors operating in Abdullah II Industrial City can be illustrated in Table (2-2) below:

Table 2.2. shows the total number of Jordanian and non-Jordanian workers and the percentage of Jordanian labor in all industrial sectors operating in Abdullah II Industrial City

\begin{tabular}{|c|c|c|c|c|}
\hline Industrial sector & $\begin{array}{l}\text { Employment } \\
\text { Jordan }\end{array}$ & $\begin{array}{l}\text { Non-Jordanian } \\
\text { employment }\end{array}$ & Total employment & $\begin{array}{l}\text { Jordanian labor } \\
\text { percentage of total } \\
\text { employment } \%\end{array}$ \\
\hline Food industries & 2821 & 632 & 3453 & 81.6 \\
\hline Pharmaceutical Industries & 1065 & 63 & 1128 & 94.4 \\
\hline $\begin{array}{c}\text { Engineering (metal and } \\
\text { electrical) }\end{array}$ & 1293 & 533 & 1826 & 70.8 \\
\hline $\begin{array}{l}\text { Plastic and rubber } \\
\text { products }\end{array}$ & 1411 & 927 & 2338 & 60.3 \\
\hline Chemical industries & 1079 & 277 & 1356 & 79.6 \\
\hline Textile and cotton & 523 & 110 & 633 & 82.6 \\
\hline $\begin{array}{l}\text { Furniture, Kitchen \& } \\
\text { Doors }\end{array}$ & 309 & 54 & 363 & 85.1 \\
\hline $\begin{array}{l}\text { Printing, paper and } \\
\text { packaging }\end{array}$ & 1924 & 1160 & 3084 & 62.3 \\
\hline Leather Industries & 17 & 4 & 21 & 81 \\
\hline Construction industries & 131 & 23 & 154 & 85 \\
\hline Total & 10573 & 3783 & 14356 & 73.6 \\
\hline
\end{tabular}

Source: Annual Report of Abdullah II Industrial City, 2017.

The sectors covered in the study (engineering, plastic, rubber, printing, paper and packaging)

Engineering Industries Sector (Metal \& Electrical)

This sector includes the manufacture of towers, equipment, electrical units, engines, metal structures, water, pipes, pumps, screws, wire, cables, machines, industrial equipment, metal forming, metal shelving, metal containers, plates, boilers, heating radiators and solar generators.

Plastic and rubber industries Sector

Including pipes, bags, furniture, paper-based industries, drip irrigation systems, bags, plastic caps, packaging and blankets.

Printing, paper and packaging industries sector

It includes the manufacture of cardboard containers, packaging rolls, paper tissue packs, paper bags, wet paper production, cardboard tubes and boxes, and the manufacture of paper napkins. (Abdullah II Industrial City, Investor's Guide and Industrial Products, 2018) 
The total number of companies and the number of Jordanian and non-Jordanian workers and the percentage of Jordanian labor in the sectors of study

The total number of companies, the number of Jordanian and non-Jordanian workers and their percentages can be shown in Table (2-3) below:

Table 2.3. shows the total number of companies, the number of Jordanian and non-Jordanian employees and the percentage of Jordanian labor in the industrial sectors under study

\begin{tabular}{cccccc}
\hline Industrial sector & $\begin{array}{c}\text { Number of } \\
\text { companies }\end{array}$ & $\begin{array}{c}\text { Employment } \\
\text { Jordan }\end{array}$ & $\begin{array}{c}\text { Non-Jordanian } \\
\text { employment }\end{array}$ & $\begin{array}{c}\text { Total } \\
\text { employment }\end{array}$ & $\begin{array}{c}\text { Percentage of Jordanian } \\
\text { labor out of total } \\
\text { employment } \%\end{array}$ \\
\hline $\begin{array}{c}\text { Engineering } \\
\text { (metal, electrical) }\end{array}$ & 71 & 1293 & 533 & 1826 & 70.8 \\
$\begin{array}{c}\text { Plastic and rubber } \\
\text { Printing, paper } \\
\text { and packaging }\end{array}$ & 84 & 1411 & 927 & 2338 & 60.3 \\
\hline Total & 188 & 1924 & 1160 & 3084 & 62.3 \\
\hline
\end{tabular}

Source: Annual Report of Abdullah II Industrial City, Investors Services Department,2018.

\section{Method and Procedures}

\section{Introduction}

In this chapter, the tools and methods used to achieve the objective of the study which aim at identification of the impact of Jordanian labor culture on the low employment rates in the sectors of engineering, plastic and rubber industries, printing, paper and packaging compared to other industrial sectors in Abdullah II Industrial City, .

\section{Methodology of the study}

The study adopted the descriptive analytical method as the appropriate method for the nature of the study. The questionnaire was distributed to the study sample and then collected to obtain the required data.

\section{Population of the Study and Study Sample}

The study population consists of the managers of the companies operating in the study sectors, which are (188) companies, as shown in Table (2-3). The sample of the study consisted of (30) companies.

\section{Sources of data acquisition}

The study relied on two types of data sources:

Secondary data: Based on the review of the various literature related to the subject of the study, published in the books and letters of the Arab and foreign universities, in addition to specialized websites.

Primary data: A questionnaire was developed as an appropriate study tool to obtain the initial data in order to answer the study questions. The questionnaire was composed of two parts. The first section included obtaining data for the sample sector.

The second part of the questionnaire included the impact of Jordanian labor culture on low operating rates in the engineering, plastic and rubber industries, printing, paper and packaging compared with other industrial sectors in Abdullah II Industrial City.

\section{Demographic variables:}

The personal characteristics of the study sample are as follows:

\section{Industrial sector variable}

The sample of the study was identified by the industrial sector. Table (3-1) shows that:

Table 3.1. Distribution of sample of study by industrial sector

\begin{tabular}{ccc}
\hline Industrial Sector Variables & Frequency & percentage $\%$ \\
\hline Engineering & 12 & 40 \\
Plastic and rubber products & 12 & 40 \\
Printing, paper and packaging & 6 & 20 \\
Total & 30 & 100 \\
\hline
\end{tabular}

\section{Results of the Study}

The study question: Is there an impact of the Jordanian labor culture on the low employment rates in the sectors of engineering, plastic and rubber industries, printing, paper and packaging compared to other industrial sectors in Abdullah II Industrial City? 
In order to answer this question, the statistical averages, standard deviations and levels of practice were calculated as the impact of the Jordanian labor culture on the low employment rates in the sectors of engineering, plastic and rubber industries, printing, paper and packaging compared with other industrial sectors from the point of view of the study sample as shawn in the following table (Table 3.2).

Table 3.2. The statistical averages, standard deviations and levels of practice have an impact of the Jordanian labor culture on the low employment rates in the engineering, plastics and rubber industries, printing, paper and packaging sectors compared to other industrial sectors

\begin{tabular}{|c|c|c|c|c|c|}
\hline number & $\begin{array}{l}\text { The field of culture of the Jordanian } \\
\text { worker }\end{array}$ & $\begin{array}{l}\text { The arithmetic } \\
\text { mean }\end{array}$ & $\begin{array}{l}\text { The standard } \\
\text { deviation }\end{array}$ & $\begin{array}{c}\text { The degree of } \\
\text { practice }\end{array}$ & Rank \\
\hline 1 & $\begin{array}{l}\text { The worker believes that the material } \\
\text { incentives are unfair in this sector }\end{array}$ & 3.7667 & .89763 & High & 5 \\
\hline 2 & $\begin{array}{l}\text { The worker believes that moral } \\
\text { incentives are unfair in this sector }\end{array}$ & 3.7333 & 1.04826 & High & 6 \\
\hline 3 & $\begin{array}{l}\text { The worker believes that work in this } \\
\text { sector is harder than work in other } \\
\text { sectors }\end{array}$ & 4.0333 & .88992 & High & 2 \\
\hline 4 & $\begin{array}{l}\text { The worker believes that the work } \\
\text { does not suit his technical abilities in } \\
\text { this sector }\end{array}$ & 3.8000 & 1.06350 & High & 4 \\
\hline 5 & $\begin{array}{l}\text { The worker believes that the work } \\
\text { does not fit his physical abilities in } \\
\text { this sector }\end{array}$ & 3.9000 & .92289 & High & 3 \\
\hline 6 & $\begin{array}{l}\text { The worker believes that the work } \\
\text { environment is not suitable for their } \\
\text { customs and traditions in this sector }\end{array}$ & 4.1667 & .94989 & High & 1 \\
\hline \multirow[t]{2}{*}{7} & $\begin{array}{l}\text { The worker believes that the work in } \\
\text { this sector is not safe for the health }\end{array}$ & 3.6333 & 1.09807 & Medium & 7 \\
\hline & Overall average & 3.8571 & .9471 & - & High \\
\hline
\end{tabular}

The results of Table (3-2) indicate that all the responses in the sample of the study to the items that illustrate the field of impact of the Jordanian labor culture on the low employment rates in the sectors of the subject of study ranged from (3.63 - 16.4) The average level of the field as a whole was 3.587 and the standard deviation is 0.947 . This is a high level according to the scale. Based on the above, we conclude that there is an impact of the Jordanian labor culture on the low employment rates in sectors of Engineering, plastic and rubber industries, Printing, paper and packaging compared with other industrial sectors from the point of view of the study sample.

The hypothesis of the study: There is no statistically significant effect at the level of significance of the Jordanian labor culture on the low employment rates in the sectors of engineering, plastic and rubber industries, printing, paper and packaging compared to other industrial sectors in Abdullah II Industrial City.

The test of this hypothesis involves the use of statistical methods appropriate to the nature of this hypothesis and the presentation of the answer and in the following table (3-3):

Table 3.3. The results of the test hypothesis study

\begin{tabular}{ccc}
\hline $\begin{array}{c}\text { Sig } \\
\text { Level of significance }\end{array}$ & $\begin{array}{c}\text { Calculated T } \\
\text { value }\end{array}$ & hypothesis \\
\hline .000 & 30.504 & Main \\
\hline
\end{tabular}

The results of the analysis indicate that there is a statistically significant effect at the level of significance of (0.05 0.05) for the Jordanian labor culture with low operating employment rates in the sectors of engineering, plastic and rubber industries, printing, paper and packaging compared to other industrial sectors in Abdullah II Industrial City. In Table (3-3), the results of the analysis showed that the calculated value of (t) is 30.504) with a significant significance level of (.000) which is less than (0.05).

\section{Conclusions and Recommendations}

\subsection{Results of the Study}

The study concluded that:

1 - The impact of the Jordanian labor culture on the low operating rates in the sectors of engineering, plastic and rubber, printing, paper and packaging compared to other industrial sectors in the city of Abdullah II Industrial, where the worker believes that the material and moral incentives unfair and equitable in these sectors than in other industrial sectors because work in the sectors subject to study is difficult under long working hours. 
2 - The work in the sectors subject to the study fit the worker technically and physically and safe health, and the working environment in these sectors appropriate to the customs and traditions of the Jordanian worker, especially that the State has prepared and provided all available means through training centers, and provide material support to the trainee.

3 - The study found that the worker's view is negative in these sectors due to the lack of awareness about the work and the family's awareness about the work environment in these sectors, which led to the Jordanian worker's distance from working in these sectors.

\subsection{Recommendations of the Study}

In light of the study results, the study recommends the following:

1 - To raise the material and moral incentives or reconsider them in the sectors studied by the competent authorities, so that they are fair and appropriate to the nature of work in these sectors within the specified working hours.

2 - The State should continue to provide all available means to prepare the worker technically and physically to work in the sectors studied through the training centers prepared for this purpose, and to motivate Jordanian workers to train and join these sectors through appropriate financial and financial support.

3 - Finding ways and means and specific programs by the concerned authorities to help educate employees and their families about the work environment in the sectors under study, which leads to motivating the Jordanian worker to work in these sectors.

\section{References}

Ababneh, A., \& Kharoun (2014). expatriate labor in Jordan: an analysis of reality and policies of substitution, the National Center for Human Resources Development.

Abdullah II Industrial City, Investor's Guide and Industrial Products, 2018.

Annual Report of Abdullah II Industrial City, 2017.

Report on the culture of work, 2016 "https://mawdoo3.com".

\section{Copyrights}

Copyright for this article is retained by the author(s), with first publication rights granted to the journal.

This is an open-access article distributed under the terms and conditions of the Creative Commons Attribution license (http://creativecommons.org/licenses/by/4.0/). 